[Agr. Biol. Chem., Vol. 36, No. 5, p. 809 816, 1972]

\title{
Genetic Block of L-Glycerol-3-phosphate : NADP Oxidoreductase in the L-Glutamic Acid-producing Glycerol Auxotroph ${ }^{\dagger}$
}

\author{
By Masakazu KIKuchi, Masaru Suzuki, Muneharu DoI \\ and Yoshio NAKAO \\ Microbiological Research Laboratories, Central Research Division, \\ Takeda Chemical Industries, Ltd,, Osaka, Japan \\ Received October 18, 1971
}

\begin{abstract}
Investigations were carried out to detect a blocked step in the glycerol biosynthesis of the glycerol auxotroph GL-21 derived from Corynebacterium alkanolyticum No. 314.

The enzyme required for the conversion of dihydroxyacetone phosphate to $\alpha$-glycerophosphate was assumed to be defective, because some of glycerol derivatives and glycerol analogues substituted for glycerol as a growth factor, in which glycerides, phospholipids, surfactants and intermediary metabolites in the glycolysis pathway were included.

To confirm this assumption, the activities of $\alpha$-glycerophosphate dehydrogenase of the mutant were compared to those of the parent. From these results, the auxotroph GL-21 was found to be deficient for a specific L-glycerol-3-phosphate: NADP oxidoreductase which is indispensable for the synthesis of glycerol.
\end{abstract}

In the previous paper of this series, ${ }^{1,21}$ the glycerol auxotroph GL-21 derived from $n$ paraffins-assimilating Corynebacterium alkanolyticum No. 314 was reported to accumulate a large amount of L-glutamic acid in the culture broth under limited supply of glycerol. This is the first example in which the permeability barrier of the cell membrane to L-glutamic acid was removed artificially by the control of cellular phospholipid content. ${ }^{1}$

Up to now, many biochemical mutants have been employed in the fields of biochemistry and fermentative production, but little attention has been paid to the carbohydraterequiring mutants, especially a glycerol auxotroph.

Recently, increased interest in the structure and the function of the cell membrane led to the induction of glycerol auxotrophs, in-

$\uparrow$ Microbial Production of L-Glutamic Acid by Glycerol Auxotrophs (Part II); Presented at the Annual Meeting of the Agricultural Chemical Society of Japan, Tokyo, April 4, 1971. dependently of the authors, by Mindich ${ }^{3)}$ and Hsu and Fox. "' They investigated the regulation of biosynthesis of various components in the living cells ${ }^{31}$ and of lactose transport through the cell membrane ${ }^{4 \prime}$ using glycerol auxotrophs.

On the other hand, there are two problems in the field of the microbial production of L-glutamic acid. One is to produce a large amount of L-glutamic acid microbiologically from $n$-paraffins and the other is to solve the mechanism of L-glutamic acid excretion through the bacterial cell membrane.

The new facts obtained by our previous experiments $^{1,2)}$ give novel and interesting information regarding the above questions. However, there remain many questions as to the physiological properties of the glycerol auxotroph.

In the present report, questions on both the growth supporting factors and the blocked step in glycerol biosynthesis of the glycerol auxotroph GL-21 were clarified. 


\section{METHODS AND MATERIALS}

Strains. Corynebacterium alkanolyticum No. 314 and Corynebacterium alkanolyticum GL-21 derived from the strain No. 314 were employed throughout this study.

Determination of bacterial growth. The determination of the bacterial growth was carried out according to the method reported previously. ${ }^{2}$ The degree of the bacterial growth was optically measured.

Enzyme assays

1) L-Glycerol-3-phosphate: $N A D(P)$ oxidoreductase. To prepare the crude enzyme, the parent strain No. 314 was grown in a 2 liter Sakaguchi flask containing $500 \mathrm{ml}$ of the following medium (per liter); glucose, $10 \mathrm{~g} ; \mathrm{Na}_{2} \mathrm{SO}_{4}, 1 \mathrm{~g} ; \mathrm{MgSO}_{4} \cdot 7 \mathrm{H}_{2} \mathrm{O}, 0.1 \mathrm{~g} ; \mathrm{Na}$-glutamate, $6.5 \mathrm{~g} ; \mathrm{K}_{2} \mathrm{HPO}_{4}, 3 \mathrm{~g} ; \mathrm{KH}_{2} \mathrm{PO}_{4}, 1 \mathrm{~g} ; \mathrm{FeSO}_{4} \cdot 7 \mathrm{H}_{2} \mathrm{O}, 50 \mathrm{mg}$; casamino acid (Difco), $0.1 \mathrm{~g}$; thiamine-HCl, $200 \mu \mathrm{g}$. The incubation was carried out for $40 \mathrm{hr}$ at $28^{\circ} \mathrm{C}$ on a reciprocal shaker. The mutant strain GL-21 was grown in the above medium supplemented with $0.5 \mathrm{~g}$ of glycerol. After the cells were harvested by centrifugation at $8,000 \mathrm{rpm}$ below $5^{\circ} \mathrm{C}$, the enzyme preparation was obtained referring to the methods of Kito and Pizer,61 and of White and Kaplan ${ }^{5}$ as follows. The cells were washed three times with distilled water and finally suspended in a concentration of $10^{10}$ cells $/ \mathrm{ml}$ in distilled water containing $1 \mathrm{mM}$ ethylenediaminetetraacetate and $1 \mathrm{~mm} 2$-mercaptoethanol. The cells were disrupted by sonic treatment for $20 \mathrm{~min}$ at $5^{\circ} \mathrm{C}$ using the KUBOTA Ultrasonic Generator KMS -250 . After centrifugation for $20 \mathrm{~min}$ at $9,000 \mathrm{rpm}$, the supernatant obtained was diluted to give the solution with the absorbance at $280 \mathrm{~m} \mu$ of approximately 1.0. The enzyme protein was precipitated by the addition of solid ammonium sulfate to the concentrations of from 40 to 75 per cent saturation. The precipitate was dissolved in a small amount of $10 \mathrm{mM}$ triethanolamine buffer $(\mathrm{pH} 7.5)$ containing $1 \mathrm{mM} 2$-mercaptoethanol and the resulting enzyme solution was dialyzed overnight at below $3^{\circ} \mathrm{C}$ against the same buffer containing $1 \mathrm{~mm} 2$-mercaptoethanol and $0.05 \mathrm{M}$ ammonium sulfate. L-Glycerol3-phosphate: $\mathrm{NAD}(\mathrm{P})$ oxidoreductase was assayed spectrophotometrically by dihydroxyacetone phosphatedependent oxidation of $\mathrm{NAD}(\mathrm{P}) \mathrm{H}_{2}$. The reaction mixture contained, per $3 \mathrm{ml} ; 100$ moles of trisaminomethane $\mathrm{HCl}$ buffer ( $\mathrm{pH} 7.8$ ), $1.5 \mu$ moles of dihydroxyacetone phosphate, $0.3 \mu$ moles of $\mathrm{NAD}(\mathrm{P}) \mathrm{H}_{2}$ and the enzyme. The substrate was omitted in the blank. The reaction was run at $30^{\circ} \mathrm{C}$ for $10 \mathrm{~min}$. The absorbance decrease at $340 \mathrm{~m} \mu$ was measured at $30 \mathrm{sec}$ intervals with Multiple Sample Absorbance Recorder (Gilford Instrument Laboratories Co., Ltd.).

2) L-Glycerol-3-phosphate : cytochrome c oxidoreductase. According to the method of Lin et al.,8) the cells, which were obtained by the method described in the above section, were suspended in $0.1 \mathrm{M}$ trisaminomethane-HCl buffer ( $\mathrm{pH} 7.4$ ) in a concentration of $10^{8}$ cells $/ \mathrm{ml}$ and disrupted by the ultrasonic treatment in the same manner as described above. The sonicate was centrifuged for $10 \mathrm{~min}$ at $0^{\circ} \mathrm{C}$ to remove the cell debris and the resulting supernatant was used as the crude enzyme. The enzyme reaction was carried out in a system with the following components: $1.0 \mathrm{ml}$ of $0.2 \mathrm{M}$ phosphate buffer $(\mathrm{pH} 7.5), 0.5 \mathrm{ml}$ of $10 \mathrm{M}$ DL- $c$-glycerophosphate, $0.1 \mathrm{ml}$ of $0.1 \% \mathrm{MTT}$ (tetrazolium dye), $0.3 \mathrm{ml}$ of $0.1 \%$ phenazine methosulfate, $0.2 \mathrm{ml}$ of $0.15 \mathrm{~N}$ potassium cyanide and cell free extract in a total volume of $3.0 \mathrm{ml}$. The reaction was carried out at $25^{\circ} \mathrm{C}$ for $5 \mathrm{~min}$. The enzyme activity was assayed spectrophotometrically by measuring the absorbance increase at $550 \mathrm{~m} \mu$ according to MT T reduction.

Determination of protein. Enzyme protein was assayed by the method of Lowry et al.9/ using bovine serum albumin as the standard.

Chemicals. $\quad n$-Paraffins $\left(\mathrm{C}_{11}-\mathrm{G}_{17}\right)$ was the product of Nikko Petrochemical Co., Ltd. Glycerol was obtained from Wako Pure Chemical Industries and dihydroxyacetone phosphate dimethylketal was from Boehringer \& Soehne GmbH Mannhein. Phosphatidylserine and cardiolipin were purchased from Nutritional Biochemicals Corporation, 2-phospho-D-glyceric acid, fructose-1-phosphate and cephalin from Sigma, glyceraldehyde-3-phosphate and lecithin from Calbiochem and DL-glyceric acid, glyceraldehyde, $\alpha$-glycerophosphate and fructose-1,6-diphosphate from Katayama Chemical Industries Co., Ltd. $\alpha$-Thioglycerol, monochlorohydrin, phosphatidylethanolamine, 1,3-dichloro2-propanol and 3-phospho-D-glyceric acid were products of Tokyo Kasei Organic Chemicals and the surfactants were those of Nikko Chemicals.

\section{RESULTS}

Growth factors for $C$. alkanolyticum $G L-21$

A variety of compounds was screened as 
TaBle I. Growth Response of C. alkanolyticum to Various Compounds

\begin{tabular}{lcc}
\hline & \multicolumn{2}{c}{ Growth } \\
\cline { 2 - 3 } & No. 314 & GL-21 \\
\hline Sugar mixture & + & - \\
Amino acid mixture & + & - \\
Vitamin mixture & + & - \\
Base mixture & + & - \\
Fatty acid mixture & + & - \\
Organic acid mixture & + & - \\
Alcohol mixture & + & - \\
Dicarboxylic acid mixture & + & - \\
Glycerol derivative mixture & + & + \\
Glycerol & + & + \\
None & + & - \\
\hline
\end{tabular}

No. 314; Prototroph, GL-21; Glycerol auxotroph.

\section{List of Compounds Tested}

\begin{tabular}{|c|c|c|}
\hline Supplement & Component & $\begin{array}{l}\text { Concen } \\
\text { tration } \\
(\mu \mathrm{g} / \mathrm{ml})\end{array}$ \\
\hline Sugar mixture & $\begin{array}{l}\text { glucose, fructose, galac- } \\
\text { tose, ribose, xylose, ara- } \\
\text { binose, mannose }\end{array}$ & 100 \\
\hline $\begin{array}{l}\text { Amino acid } \\
\text { mixture }\end{array}$ & casamino acid & 500 \\
\hline Vitamin mixture & $\begin{array}{l}\text { vitamin } \mathrm{B}_{1}, \mathrm{~B}_{2}, \mathrm{~B}_{6}, \mathrm{~B}_{12} \text {, } \\
\text { inositol, choline, biotin, } \\
\text { pantothenic acid, nico- } \\
\text { tinic acid, PABA, folic } \\
\text { acid }\end{array}$ & $0.01 \sim 1$ \\
\hline Base mixture & $\begin{array}{l}\text { adenine, guanine, cyto- } \\
\text { sine, uracil, thymine, } \\
\text { xanthine, hypoxanthine, } \\
\text { inosine }\end{array}$ & 20 \\
\hline Fatty acid mixture & $\begin{array}{l}\text { fatty acids }\left(\mathrm{C}_{10}, \mathrm{C}_{12}, \mathrm{C}_{14}\right. \\
\left.\mathrm{C}_{16}, \mathrm{C}_{18} \text { and } \mathrm{C}_{18}=\right)\end{array}$ & 20 \\
\hline $\begin{array}{l}\text { Organic acid } \\
\text { mixture }\end{array}$ & $\begin{array}{l}\text { acetate, lactate, pyruvate, } \\
\text { oxalacetate, citrate, } \alpha \text { - } \\
\text { ketoglutarate, fumarate, } \\
\text { malate, glyoxylate }\end{array}$ & 20 \\
\hline Alcohol mixture & $\begin{array}{l}\text { methanol, ethanol, pro- } \\
\text { panol, ethylenglycol, pro- } \\
\text { pylenglycol, polyethylen- } \\
\text { glycol, polypropylen- } \\
\text { glycol }\end{array}$ & 20 \\
\hline $\begin{array}{l}\text { Dicarboxylic acid } \\
\text { mixture }\end{array}$ & $\begin{array}{l}\text { oxalate, succinate, malo- } \\
\text { nate, glutarate, adipate, } \\
\text { pimelate, suberate, aze- } \\
\text { late, sebacate }\end{array}$ & 20 \\
\hline $\begin{array}{l}\text { Glycerol derivative } \\
\text { mixture }\end{array}$ & $\begin{array}{l}\text { EMP member, }{ }^{a} \text { lipid, } \\
\text { surfactant }\end{array}$ & 100 \\
\hline
\end{tabular}

the indispensable factor for the growth of the glycerol auxotroph GL-21 and results were shown in Table I. The kinds of compounds and their concentrations supplied were shown at the botton of Table I. As is clear from the results, the prototroph No. 314 could grow regardless of the addition of any compound, while the auxotroph GL-2l was found to grow only on the media supplemented with glycerol or glycerol related compounds. None of amino acids, vitamins, nucleic acid bases, fatty acids, organic acids, alcohols and dicarboxylic acids could substitute for glycerol.

\section{Growth supporting effect of glycerol related com- pounds}

Among many glycerol related compounds, some intermediary metabolites in the glycolysis pathway were first examined for the substituting effect for glycerol. The results shown in Table II indicate that the glycerol auxotroph GL-21 could grow on the media containing $\alpha$-glycerophosphate, glyceraldehyde or glycerate. The dephospholylation by phosphatase of this strain will be responsible for the weak utilization of 3-phosphoglycerate and glyceraldehyde-3-phosphate. Fructose-1phosphate and fructose-1,6-diphosphate could not serve as a growth factor. In view of the results described above, the effect of these

TABLE II. GROWTH Response of C. alkanolyticum to Glycerol Related Compounds

\begin{tabular}{lcc}
\hline & \multicolumn{2}{c}{ Growth } \\
\cline { 2 - 3 } Supplement $(100 \mu \mathrm{g} / \mathrm{ml})$ & No. 314 & GL-21 \\
\hline 3-Phosphoglycerate & $\#$ & \pm \\
Glyceraldehyde-3-phosphate & $\#$ & \pm \\
$\alpha$-Glycerophosphate & $\#$ & + \\
Glyceraldehyde & + & + \\
Glycerate & $\#$ & + \\
Fructose-1-phosphate & $\#$ & - \\
Fructose-1,6-diphosphate & $\#$ & - \\
Glycerol & $\#$ & $\#$ \\
None & $\#$ & - \\
\hline
\end{tabular}

No. 314; Prototroph, GL-21; Glycerol auxotroph. 
TABLE III. GROWTH RESPONSE OF C. alkanolyticum to Glycerol Derivatives

\begin{tabular}{lcc}
\hline \multirow{2}{*}{ Supplement $(100 \mu \mathrm{g} / \mathrm{ml})$} & \multicolumn{2}{c}{ Growth } \\
\cline { 2 - 3 } & No. 314 & GL-21 \\
\hline$\alpha$-Monochlorohydrin & + & + \\
Glycerol- $\alpha, \alpha^{\prime}$-dichlorohydrin & + & + \\
$\alpha$-Thioglycerol & + & + \\
$\alpha, \alpha^{\prime}$-Glycerol diethyl ether & $\#$ & \pm \\
Batyl alcohol & $\#$ & \pm \\
Propionate & $\#$ & - \\
Glycerol & $\#$ & $\#$ \\
None & $\#$ & - \\
\hline
\end{tabular}

No. 314; Prototroph, GL-21; Glycerol auxotroph.

$$
\stackrel{\mathrm{CH}_{2} \mathrm{OH}}{\mathrm{CHOH}}
$$

Glycerol

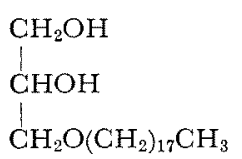

Batyl alcohol

$$
\begin{aligned}
& \mathrm{CH}_{2} \mathrm{SH} \\
& \stackrel{\mathrm{CHOH}}{\mathrm{C}} \mathrm{H}_{2} \mathrm{OH}
\end{aligned}
$$$$
\alpha \text {-Thioglycerol }
$$

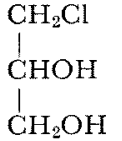

Monochlorohydrin

$\mathrm{CH}_{3}$
$\mathrm{CH}_{2}$
$\mathrm{COOH}$

FIG. 1. Structure of Glycerol Derivatives.

compounds on the glycerol auxotroph GL-21 seemed to be attributable to a glycerol skeleton in their chemical structure. The effect of glycerol derivatives and glycerol analogues were next examined.

As is demonstrated in Table III, $\alpha$-monochlorohydrin, glycerol- $\alpha, \alpha^{\prime}$-dichlorohydrin and $\alpha$-thioglycerol supported the growth of the strain GL-21, however, propionate had no effect. Namely, the chemicals, in which the hydroxy group at $\alpha$-or $\alpha^{\prime}$-position was replaced by hydrogen sulfite or chlor radical, satisfied the auxotrophic requirement of strain GL-21. In retrospect of the chemical structures indicated in Fig. 1, chemicals having an ether bond such as $\alpha, \alpha^{\prime}$-glycerol diethyl ether and batyl alcohol appear to be difficult to serve as growth factors, even if a glycerol skeleton is in their structure. The typical lipids were next selected to be tested as the substitution for glycerol. As is shown in Table IV, glycerides, such as monoolein, monopalmitin, triolein and tripalmitin, and phospholipids, such as lecithin and phosphatidylethanolamine, came to light as growth factors, but the effect of cardiolipin, which inhibited the growth of the prototroph No. 314, remained unknown.

TABLE IV. GROWTH RESPONSE OF C. alkanolyticum

\begin{tabular}{|c|c|c|c|}
\hline \multirow{2}{*}{$\begin{array}{l}\text { Supplement } \\
(100 \mu \mathrm{g} / \mathrm{ml})\end{array}$} & \multirow{2}{*}{$\begin{array}{l}\text { Fatty acid } \\
\text { component }\end{array}$} & \multicolumn{2}{|c|}{ Growth } \\
\hline & & No. 314 & GL-21 \\
\hline PMS-SE & $\mathrm{C}_{18}$ & $H$ & $H$ \\
\hline$A-1000$ & $\mathrm{C}_{18}$ & $H$ & $\#$ \\
\hline$A-2000$ & $\mathrm{C}_{18}=$ & H & $H$ \\
\hline A-3100 & $\mathrm{C}_{12}$ & H & $H$ \\
\hline $\mathrm{SO}-10$ & $\mathrm{C}_{18}=$ & $H$ & - \\
\hline $\mathrm{SO}-30$ & $\mathrm{C}_{18}=$ & $H$ & - \\
\hline TO- 10 & $\mathrm{C}_{18}=$ & $H$ & - \\
\hline $\mathrm{MGO}$ & $\mathrm{C}_{18}=$ & $H$ & $H$ \\
\hline Oleic acid & & + & - \\
\hline Linoleic acid & & H & - \\
\hline Elaidic acid & & H & - \\
\hline None & & $H$ & - \\
\hline
\end{tabular}
TO LIPIDS

\begin{tabular}{lcc}
\hline \multirow{2}{*}{ Supplement $(100 \mu \mathrm{g} / \mathrm{ml})$} & \multicolumn{2}{c}{ Growth } \\
\cline { 2 - 3 } & No. 314 & $\mathrm{GL}-21$ \\
\hline Monomyristin & $\#$ & $\#$ \\
Monopalmitin & $\#$ & $\#$ \\
Monostearin & $\#$ & $\#$ \\
Monoolein & $\#$ & $\#$ \\
Tripalmitin & $\#$ & $\#$ \\
Triolein & $\#$ & $\#$ \\
Cardiolipin & \pm & \pm \\
Lecithin & + & + \\
Phosphatidylserine & $\#$ & + \\
Phosphatidylethanolamine & $\#$ & + \\
None & $\#$ & - \\
\hline
\end{tabular}

No. 314; Prototroph, GL-21; Glycerol auxotroph.

TABLE V. GROWTH RESPONSE OF C. alkanolyticum TO SURFACTANTS AND FATTY ACIDS

No. 314; Prototroph, GL-21; Glycerol auxotroph. 


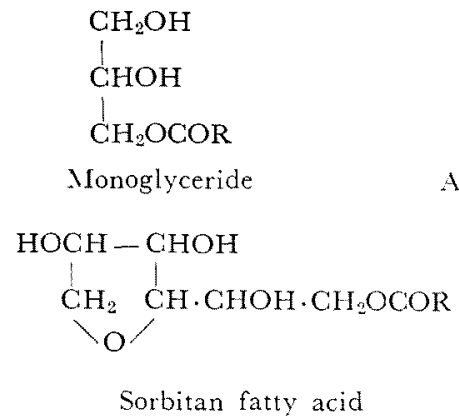

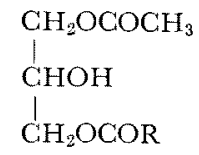

Acetyl monoglyceride

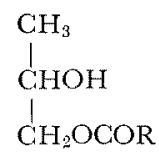

Propylene glycol fatty acid

FIG. 2. Structure of Surfactants.

On the other hand, the auxotrophic requirement of this mutant was satisfied by some surfactants. As is indicated in Table V, these were propylene glycol fatty acid (PMSSE) and acetyl monoglyceride (A-1000, A-2000 and A-3100) which have a glycerol or a glycerol-like skeleton as shown in Fig. 2. On the contrary, it is well known that some of the fatty acids or surfactants ${ }^{10,11}$ reveal the growth-supporting effect for a biotin-requiring Brevibacterium sp. in L-glutamic acid fermentation from carbohydrates. In this experiment, unsaturated fatty acids, such as oleic acid and linoleic acid, and surfactants, such as sorbitan monooleate (SO-10) and polyoxyethylene sorbitan monooleate ( $\mathrm{TO}-10$ ), were investigated as to the growth factor in comparison with surfactants described above. However, all of the samples, except glycerol- $\alpha$-monooleate, had no effects. Namely, these facts indicate that a biotin auxotroph requires unsaturated fatty acids for its growth, while a glycerol auxotroph requires glycerol as a growth factor. In the light of these results, these two strains were found to be essentially different from each other.

From the investigations described above, it was concluded that the glycerol auxotroph GL-21 could grow on the media supplemented by glycerol derivatives or analogues, in which glycerol or glycerol-like skeleton is present in their structures. Moreover, evidence was presented that there was no relation between the substituting effect for glycerol and the kind of fatty acid composition in the substitutant.

\section{Assay of L- $\alpha$-glycerophosphate dehydrogenase ac- tivities}

From a consideration of the results summarized in Fig. 3, the glycerol requirement of the strain GL-21 appeared to arise from the lack of an enzyme catalizing the reaction between dihydroxyacetone phosphate and $\alpha$ glycerophosphate. The enzymes participating in this step are L-glycerol-3-phosphate:

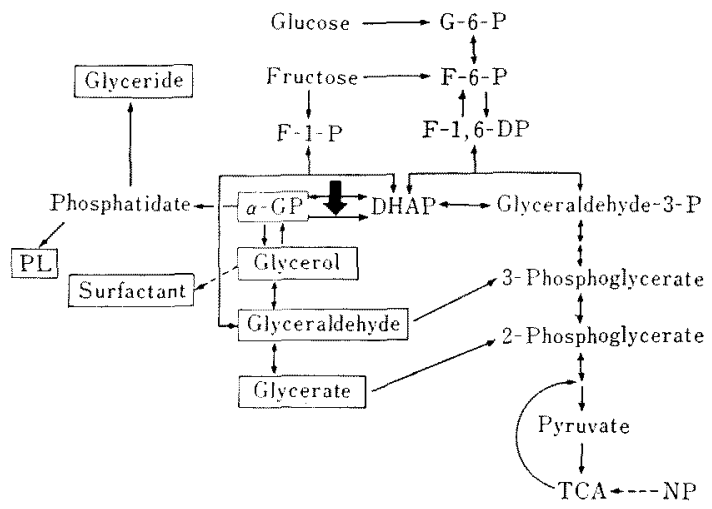

FIG. 3. Proposed Step Blocked in Glycerol Biosynthesis in $C$. alkanolyticum GL-21.

Abbreviations:

G-6-P, glucose-6-phosphate; F-6-P, fructose-6. phosphate; F-1-P, fructose-1-phosphate; F-1,6-DP, fructose-1,6-diphosphate; $\alpha$-GP, $\alpha$-glycerophosphate; DHAP, dihydroxyacetone phosphate; Glyceraldehyde-3-P, glyceraldehyde-3-phosphate; PL, phospholipid; NP, n-paraffins.

: Growth supporting compound. 
Table Vi. Activities of L-Glycerol-3Phosphate : NAD(P) Oxidoreductase

\begin{tabular}{llrc}
\hline Strain & Cofactor & $\begin{array}{c}\text { Enzyme } \\
\text { protein }\end{array}$ & Activity $^{b}$ \\
\hline No. 314 & $\mathrm{NADPH}_{2}$ & 8.1 & $5.92 \times 10^{-4}$ \\
No. 314 & $\mathrm{NADH}_{2}$ & 8.1 & - \\
GL-21 & $\mathrm{NADPH}_{2}$ & 15.9 & - \\
GL-21 & $\mathrm{NADH}_{2}$ & 15.9 & - \\
\hline
\end{tabular}

a) $\mathrm{mg}$.

b) $-\Delta E_{340} / \mathrm{min} / \mathrm{mg}$ protein.

The reaction mixture contained 100 mmoles of TrisHCl buffer ( $\mathrm{pH} 7.8$ ), 1.5 mmoles of dihydroxyacetone phosphate, $0.3 \mu$ moles of $\mathrm{NAD}(\mathrm{P}) \mathrm{H}_{2}$ and enzyme solution in a total volume of $3.0 \mathrm{ml}$, and was incubated for $10 \mathrm{~min}$ at $30^{\circ} \mathrm{C}$.

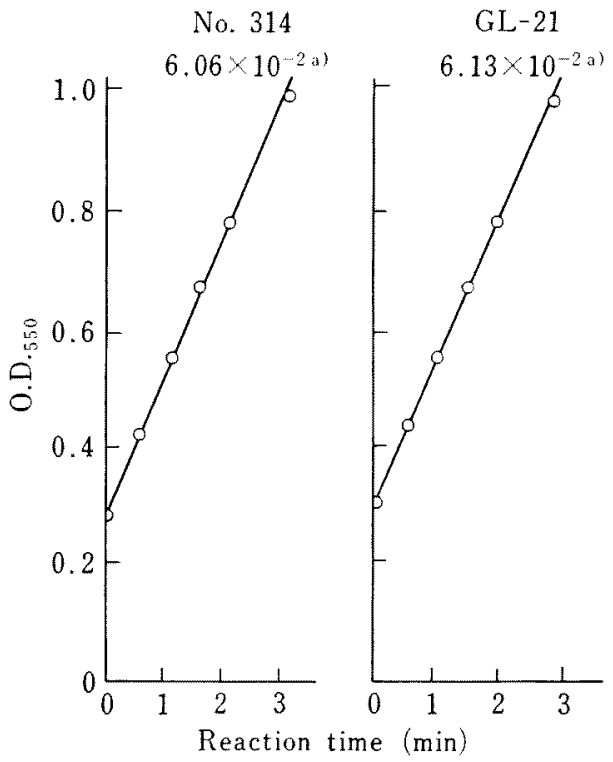

FIG. 4. Activities of L-Glycerol-3-phosphate: cytochrome $c$ Oxidoreductase.

a) Enzyme activity ( $\Delta E_{550} / \mathrm{min} / \mathrm{mg}$ protein).

The reaction mixture contained $1.0 \mathrm{ml}$ of $0.2 \mathrm{M}$ phosphate buffer ( $\mathrm{pH} 7.5$ ), $0.5 \mathrm{ml}$ of $10 \mathrm{M} \mathrm{DL-} \alpha$ glycerophosphate, $0.1 \mathrm{ml}$ of $0.1 \%$ MTT (tetrazolium dye), $0.3 \mathrm{ml}$ of $0.1 \%$ phenazine methasulfate, 0.2 $\mathrm{ml}$ of $\mathrm{KCN}$ and enzyme solution in a total volume of $3.0 \mathrm{ml}$, and was incubated for $3 \mathrm{~min}$ at $25^{\circ} \mathrm{C}$.

NAD $(\mathrm{P})$ oxidoreductase (1) and L-glycerol-3phosphate: cytochrome c oxidoreductase (2), respectively.
To confirm the above assumption, the enzyme activity of both the parent and the mutant was compared, using the partially purified enzyme preparations. As will be seen from Table VI, the enzyme (1) from the strain No. 314 proved to be dependent on $\mathrm{NADPH}_{2}$, but not on $\mathrm{NADH}_{2}$. In the case of the strain GL-21, activity of enzyme (1) was not recognized by the addition of either $\mathrm{NADPH}_{2}$ or $\mathrm{NADH}_{2}$.

The activity of the enzyme (2), which catalizes an NAD or NADP independent biosynthesis of dihydroxyacetone phosphate (DHAP) from $\alpha$-glycerophosphate was next examined. As is indicated in Fig. 4, activity of the enzyme (2) was recognized in the crude enzyme preparation from both the strain No. 314 and the strain GL-21 and no difference could be detected between the two. From the results obtained, the prototroph No. 314 was found to have both enzymes (1) and (2), while the auxotroph GL-21 had only the enzyme (2). Namely, the glycerol auxotroph GL-2l was defective in a specific L$\alpha$-glycerol-3-phosphate: NADP oxidoreductase required for the synthesis of glycerol.

\section{DISCUSSION}

Production of L-glutamic acid fermentatively from carbohydrates by a biotin ${ }^{12)}$ or an oleic $\operatorname{acid}^{131}$ auxotroph is well known, however, no technique superior to the method of penicillin addition $^{14,15)}$ had been accepted for producing L-glutamic acid from $n$-paraffins, until our new procedure using the glycerol auxotroph ${ }^{1,21}$ was developed. In fact, the penicillin addition method did not seem to be always adequate to produce L-glutamic acid from $n$-paraffins, because of the great difficulty in controlling the fermentation process and in removing the by-products such as phospholipids and glucosamine $^{16 /}$ with this method.

In view of these facts, the utilization of this glycerol auxotroph will be expected to open a new field and to play a new role in 
both fermentation production and biochemical studies. This expectation was realized through the induction of another glycerol auxotroph, almost independently of the authors, from Bacillus subtilis by Mindich ${ }^{31}$ and from Escherichia coli by Hsu and Fox. ${ }^{41}$

In this paper, the purpose was to clarify the nutrient requirement and the blocked step in glycerol biosynthesis of this mutant GL-21. The auxotrophic requirement of this mutant GL-21 was satisfied by glycerol, glycerol derivatives and glycerol analogues. In the light of these results, it is believed that the glycerol skeleton in these chemicals is a main factor to support the mutant growth. Among the compounds satisfying this requirement, batyl alcohol and glycerol diethyl ether, which have an ether bond in their structures, were found to be difficult to substitute for glycerol. Moreover, fatty acids and surfactants effective for the growth of a biotin auxotroph ${ }^{11,12}$ used in L-glutamic acid fermentation, were found ineffective for the growth of this mutant GL-21, except a surfactant having a glycerol skeleton in its structure.

It is a very interesting problem at this point to clarify the incorporation mechanism of glycerol derivatives and glycerol analogues into the cells. Partial studies on the incorporation of $\alpha$-thioglycerol and $\alpha$-monochlorohydrin suggested that these chemicals would be incorporated after decomposition to glycerol and hydrogen sulfite or hydrogen chloride. However, further work is necessary for clarification.

Studies on the auxotrophic requirement of the strain GL-21 suggested genetic block of $\alpha$-glycerophosphate dehydrogenase catalizing the reaction between dihydroxyacetone phosphate and $\alpha$-glycerophosphate. Hsu and Fox ${ }^{41}$ reported the defect of L-glycerol-3-phosphate: NADP oxidoreductase in a glycerol auxotroph of $E$. coli using the crude enzyme preparation separated by supercentrifugation. In the case of a glycerol auxotroph of Bacillus subtilis, assay of the above enzyme activity ended in failure because of the difficulty in extracting the enzyme. The existence of $\mathrm{NAD}(\mathrm{P}) \mathrm{H}_{2}$ oxidase in the crude enzyme preparation of C. alkanolyticum was responsible for the difficulty in the assay of enzyme activity, but the partially purified enzyme preparation obtained by ammonium sulfate fractionation led to success in the measurement of the enzyme activity in the present experiment. Further studies on L-glycerol-3-phosphate: cytochrome c oxidoreductase showed the same activity in the crude enzyme preparations of both the prototroph and the auxotroph. As a consequence, glycerol requirement of this mutant GL-21 was concluded to stem from the lack of L-glycerol-3-phosphate: NADP oxidoreductase.

The greater part of lipids in Corynebacterium sp. is thought to be phospholipids which appear to play an important role in controlling the permeability to L-glutamic acid through the cell membrane, however, details remain unknown. The finding of this type of mutant proved to make it possible to regulate lipid content, resulting in the excretion of a large amount of L-glutamic acid into the broth. ${ }^{11}$

The relation between membrane phospholipids and L-glutamic acid excretion will be clarified in a latter paper.

Acknowledgement. The authors are grateful to Dr. M. Kito of Research Institute for Food Science, Kyoto University for his helpful advice in obtaining the preparation of L-glycerol-3-phosphate: NADP oxidoreductase.

Thanks are also due to Drs. R. Takeda, Y. Ishida and H. Fukuda of Takeda Chemical Industries, Ltd. for their continuing interest and encouragement.

\section{REFERENCES}

1) Y. Nakao, M. Kikuchi, M. Suzuki and M. Doi, Agr. Biol. Chem., 34, 1875 (1970).

2) Y. Nakao, M. Kikuchi, M. Suzuki and M. Doi, ibid., 36, 490 (1972). 
3) L. Mindich, J. Mol. Biol., 49, 415 (1970).

4) C. C. Hsu and C. F. Fox, J. Bacteriol., 103, 410 (1970).

5) M. Kito and L. I. Pizer, Biochem. Biophys. Res. Commun., 32, 408 (1968).

6) M. Kito and L. I. Pizer, J. Biol. Chem., 244, 3316 (1969).

7) H. B. White and N. O. Kaplan, ibid., 244, 6031 (1969).

$8)$ E. C. C. Lin, J. P. Koch, T. M. Chused and S. E. Jorgensen, Proc. Natl. Acad. Sci. U.S., 48, 2145 (1962).

9) O. H. Lowry, N. J. Rosebrough, A. L. Farr and R. J. Randell, J. Biol. Chem., 193, 265 (1951).

10) K. Miyai, K. Goto, I. Tsuruo, R. Kodaira and T. Akimoto, Nippon Nogeikagaku Kaishi, 37, 37
(1963).

11) K. Takinami, H. Yoshii, Y. Yamada, H. Okada and K. Kinoshita, Amino Acid and Nucleic Acid, 18, 120 (1968).

12) K. Tanaka, T. Iwasaki and S. Kinoshita, Nippon Nogeikagaku Kaishi, 34, 593 (1960).

13) T. Kanzaki, K. Isobe, H. Okazaki, K. Motizuki and H. Fukuda, Agr. Biol. Chem., 31, 1307 (1967).

14) S. Otsuka, R. Ishii, I. Shiio and N. Katsuya, J. Gen. Appl. Microbiol., 10, 179 (1964).

15) T. Iguchi, S. Hayakawa and I. Takeda, Nippon Nogeikagaku Kaishi, 40, 26 (1966).

16) M. Kikuchi, A. Sugahara, M. Doi, M. Suzuki and Y. Nakao, Abstracts of Papers, Annual Meeting of the Agricultural Chemical Society of Japan, Tokyo, April, 1969, p. 185. 